\title{
PENDEKATAN SAINTIFIK DALAM PENGEMBANGAN BAHASA ANAK DI TAMAN KANAK-KANAK ASOKA KOTA MAKASSAR
}

\section{Scientific Approach in Language Development of Children in Kindergarten Asoka Makassar}

\author{
Marwah, ${ }^{1}$ Tawany Rahamma ${ }^{2}$, Muh. Nadjib ${ }^{3}$ \\ ${ }^{1}$ Universitas Hasanuddin Makassar, (Email:marwah.dumessaa@gmail.com) \\ ${ }^{2}$ Universitas Negeri Makassar, (Email: Tawanirahamma@gmail.com) \\ ${ }^{3}$ Universitas Hasanuddin Makassar, (Email: Nadjib.mn@gmail.com)
}

\begin{abstract}
ABSTRAK
Pendekatan Saintifik sangat mendukung perkembangan bahasa anak. Penelitian ini bertujuan (1) Untuk mengetahui pelaksanaan pendekatan saintifik dalam pembelajaran bahasa anak di taman kanak kanak Asoka kota Makassar, (2) Untuk mengetahui tingkat perkembangan bahasa anak di taman kanak kanak Asoka kota Makassar, (3) Untuk mengetahui hubungan pelaksanaan pendekatan saintifik terhadap tingkat perkembangan bahasa anak di taman kanak kanak Asoka kota Makassar. Penelitian ini bersifat deskriptif kualitatif. Hasil penelitian menunjukkan bahwa (1)Pelaksanaan pendekatan saintifik dalam pengembangan bahasa anak melalui tahapan mengamati, menanya, mengumpulkan informasi, mengasosiasi, mengkomunikasikan terlaksana dalam kegiatan pembelajaran disetiap sentra pembelajaran, (2)Perkembangan bahasa anak mencakup aspek bahasa anak yaitu, menyimak, berbicara, membaca dan menulis untuk meningkatkan kemampuan berbahasa anak, perkembangan bahasa anak usia 5-6 tahun mengarah kepada Berkembang Sangat Baik, dan untuk anak usia 4-5 tahun mengarah kepada Berkembang Sesuai Harapan, (3)Terdapat hubungan pendekatan saintifik dengan perkembangan bahasa anak, dengan pendekatan saintifik memunculkan motivasi anak untuk belajar melalui bermain.
\end{abstract}

Kata kunci: Pendekatan Saintifik, Pengembangan Bahasa Anak

\begin{abstract}
Scientific approach strongly supports the development of children's language. This study aims to (1) To investigate the implementation of the approach scientific language learning of children in kindergarten Asoka city of Makassar, (2) To determine the level of language development of children in kindergarten Asoka Makassar, (3) To determine the relationship implementation approach scientific to the level of language development of children in kindergarten Asoka Makassar. This research is descriptive qualitative. The results showed that (1) Implementation of the scientific approach in language development of children through the stages observe, ask, gather information, associate, communicate accomplished in each learning activity learning centers, (2)The development of children's language includes aspects of children's language, namely, listening, speaking, reading and writing to improve children's language skills, language development of children aged 5-6 years leads to Developing Very Good, and for children aged 4-5 years leads to Developing accordance Hope, (3) An association of scientific approach to the development of children's language, with a scientific approach to the motivation for children to learn through play.
\end{abstract}

Keywords: Scientific Approach, Children's Language Development 


\section{PENDAHULUAN}

Usia emas atau golden age adalah masa yang paling penting dalam proses kecerdasan anak. Dalam usia 0-6 tahun, anak diajarkan berbagai macam pendidikan dasar, mulai dari berbicara, bersikap, bermain, hingga diajarkan untuk belajar pelajaranpelajaran ringan. Pendidikan Anak Usia Dini (PAUD) adalah salah satu cara untuk meningkatkan kualitas anak didik sejak usia dini.

Pendidikan Anak Usia Dini merupakan salah satu bentuk penyelenggaraan pendidikan yang menitikberatkan pada peletakan dasar ke arah pertumbuhan dan perkembangan fisik (koordinasi motorik halus dan kasar), kecerdasan (daya pikir, daya cipta, kecerdasan emosi, kecerdasan spiritual), sosio emosional (sikap dan perilaku serta agama) bahasa dan komunikasi, sesuai dengan keunikan dan tahap-tahap perkembangan yang dilalui oleh anak usia dini.

Bermain membantu mengembangkan berbagai potensi anak. Melalui bermain anak diajak bereksplorasi, menemukan, dan memanfaatkan objek-objek yang dekat dengan anak, sehingga pembelajaran menjadi bermakna bagi anak. Bermain merupakan kegiatan yang paling diminati anak. Saat bermain anak melatih otot besar dan kecil, melatih keterampilan berbahasa, menambah pengetahuan, melatih cara mengatasi masalah, mengelola emosi, bersosialisasi, mengenal matematika, sains, dan banyak hal lainnya.

Pembelajaran yang dikelola baik sesuai kebutuhan dan karakteristik anak, dapat mengoptimalkan potensi kecerdasan jamak yang dimiliki anak sejak dini. Proses pembelajaran merupakan sarana untuk menstimulasi kecerdasan anak, oleh karena itu pemilihan metode, strategi, media dan pendekatan dalam proses pembelajaran harus sesuai tema dan materi pembelajaran dalam kurikulum. Implementasi dari kurikulum 2013 dalam proses pembelajaran anak usia dini adalah pendekatan Saintifik. Pembelajaran dilaksanakan melalui pendekatan saintifik melalui tahap mengamati, menanya, mengumpulkan informasi, menalar dan mengkomunikasikan.

Perkembangan Bahasa untuk anak usia dini meliputi empat pengembangan yaitu menyimak, berbicara, membaca dan menulis. Pengembangan kemampuan berbahasa Anak
Usia Dini bertujuan agar anak didik mampu berkomunikasi secara lisan dengan lingkungannya.

Rogers dkk dalam Cangara (2012), bahwa : "Komunikasi adalah suatu proses dimana dua orang atau lebih membentuk atau melakukan pertukaran informasi dengan satu sama lainnya, yang pada gilirannya akan tiba pada saling pengertian yang mendalam.

Komunikasi tidak pernah terlepas dari sebuah proses, oleh karena itu apakah pesan dapat tersampaikan atau tidak tergantung dari proses komunikasi yang terjadi. Menurut Harapan \& Ahmad (2014), proses komunikasi dapat terjadi bila sumber (comunicator) bermaksud menyampaikan gagasan (informasi, sasaran, permintaan dan seterusnya) yang ingin disampaikan kepada penerima dengan maksud tertentu. Untuk itu dia menerjemahkan gagasan tersebut menjadi simbol-simbol (proses encoding) yang selanjutnya disebut pesan (message).

Menurut Harun Rasyid, Mansur \& Suratno (2009), bahasa merupakan struktur dan makna yang bebas dari penggunanya, sebagai tanda yang menyimpulkan suatu tujuan. Sedangkan bahasa menurut Badudu dalam Gunarti, dkk, ( 2008), bahasa adalah alat penghubung atau komunikasi antar anggota masyarakat yang terdiri dari individuindividu yang menyatakan pikiran, perasaan dan keinginannya. Bahasa berarti system lambang bunyi yang arbitrer, yang digunakan oleh semua orang atau anggota masyarakat untuk bekerjasama, berinteraksi, dan mengidentifikasi diri dalam bentuk percakapan yang baik, tingkah laku yang baik, sopan santun yang baik.

Pendekatan saintifik adalah proses pembelajaran yang dirancang sedemikian rupa agar peserta didik secara aktif mengkonstruk kompetensi sikap, pengetahuan, dan keterampilan melalui tahapan mengamati, menanya, mengumpulkan informasi, menalar, dan mengomunikasikan.

Menurut hasil penelitian Munastiwi (2015), menunjukkan bahwa Pendekatan ilmiah mampu membangun kreativitas, imajinasi dan mengembangkan nilai-nilai agama dan moralitas, motorik, kognitif, bahasa, sosial, emosional dan seni berdasarkan pada prinsip-prinsip perkembangan anak. Oleh karena itu, pelaksanaan pendekatan ilmiah dalam proses pembelajaran pendidikan anak 
usia dini dapat mengasah kecerdasan spiritual dan intelektual anak-anak.

$$
\text { Menurut hasil penelitian }
$$

Wahyuningsih (2015), menunjukkan bahwa implementasi kurikulum 2013 PAUD dengan pendekatan saintifik meliputi proses mengamati, menanya, mengumpulkan informasi, mengasosiasi, dan mengkomunikasikan. Implementasi kurikulum 2013 tersebut didukung oleh beberapa faktor yaitu kemampuan tenaga pendidik, lembaga, sarana dan prasarana dan APE.

Tujuan yang diharapkan tercapai dalam penelitian ini untuk Mengetahui pelaksanaan pembelajaran bahasa melalui pendekatan saintifik dan perkembangan bahasa anak di Taman Kanak Kanak Asoka Kota Makassar.

\section{BAHAN DAN METODE Pendekatan Penelitian}

Penelitian ini menggunakan pendekatan penelitian kualitatif deskriptif, yakni penelitian yang menggunakan cara berpikir induktif yaitu cara berpikir yang berangkat dari hal-hal yang khusus (fakta empiris) menuju hal-hal yang umum (tataran konsep).

\section{Lokasi dan Waktu Penelitian}

Penelitian ini dilakukan di Taman KanakKanak Asoka Kota Makassar. Penelitian dilakukan selam 3 (tiga) bulan yakni mulai bulan Maret sampai bulan Mei 2016.

\section{Teknik pengumpulan data}

Wawancara kepada Kepala Sekolah dan Para Pengajar/Guru Taman Kanak-Kanak Asoka. Peneliti melakukan observasi partisipatif pada Taman Kanak-Kanak Asoka untuk mendapatkan data yang valid dan real serta hasil penelitian yang maksimal. Dokumen dan arsip merupakan bahan tertulis yang berhubungan dengan suatu peristiwa tertentu. Dokumen berupa catatan guru tentang perkembangan bahasa anak dan persiapan mengajar guru.

\section{Teknik analisis Data}

Dalam penelitian ini, peneliti menggunakan model analisis interaktif. Pada dasarnya model analisis interaktif proses berbentuk siklus, yang artinya pada bentuk ini peneliti tetap bergerak diantara tiga komponen analisis dengan proses pengumpulan data selama kegiatan pengumpulan berlangsung. Sesudah pengumpulan data berakhir, maka peneliti bergerak diantara tiga komponen analisanya.

\section{HASIL PENELITIAN \\ Pendekatan Saintifik Dalam Pembelajaran Bahasa Anak Di TK Asoka Makassar}

Dilaksanakan dengan model sentra yakni : untuk kelas B sebanyak 6 sentra yaitu untuk sentra balok, seni, persiapan, bahan alam, bermain peran, imtaq. Untuk kelas A sebanyak 3 sentra yaitu bahan alam, seni, persiapan. Kegiatan awal setiap hari murid TK Asoka yakni dimulai dengan berbaris didepan kelas dipandu ibu guru, kemudian sebelum masuk kelas menyimpan tas diloker dan masuk kelas kemudian pada saat sentra murid akan moving class.

Rencana kegiatan harian (RKH) atau RPP menjadi pedoman dalam pelaksanaan kegiatan belajar mengajar. Kegiatan main pendekatan saintifik untuk anak usia 5-6 tahun disetiap sentra yakni pada sentra balok: anak membangun rumah dari balok. Pada kegiatan ini anak melakukan kegiatan pengamatan, mendapatkan informasi tentang membangun rumah dan fungsi-fungsi bagian rumah, mengasosiasi dan mengkomunikasikan dengan yang lain. Sentra bermain peran: bermain Peran tentang aktivitas penjual dan pembeli/makan direstoran. Anak membangun kemampuan melalui pendekatan saintifik dengan cara melakukan, bukan didikte ataupun hafalan. Pada kegiatan diatas anak-anak terlibat diskusi tentang peran yang dilakoni, anak sudah memiliki konsep sosial tentang pekerjaan, ketekunan, membangun percaya diri, mengkomunikasikan hasil. Sentra bahan alam: Bermain tentang penyerapan sari makanan oleh tanaman.Kegiatan mengamati dapat dilakukan bersama-sama didalam atau diluar kelas. Media untuk diamati bisa apapun. Media disiapkan sesuai dengan tema yang sedang dipilih. Pada saat kegiatan anak melakukan kegiatan pengamatan, mendapatkan informasi tentang cara tanaman menyerap makanan dari dalam tanah, mengasosiasi dan mengkomunikasikan pada yang lain. Sentra Seni: anak mencocok air terjun, menempel air terjun, menggambar tempat rekreasi, Pada kegiatan diatas yakni pada saat anak mencocok air terjun dan menempel serta menggambar tempat rekreasi melalui proses saintifik anak melakukan kegiatan mengamati, menanya, mengumpulkan informasi dari bahan yang digunakan, mengasosiasi dan mengkomunikasikan dengan terlibat diskusi 
tentang tempat rekreasi. Sentra persiapan: anak bermain tentang ciri dan makanan khas makassar, menulis angka dan mengklasifikasi warna jepitan Pada pembelajaran ini anak melakukan kegiatan mengamati penulisan angka-angka, mengasosiasi, mengumpulkan informasi, mengkomunikasikan terkait makanan khas Makassar. Sentra imtaq: Bercerita tentang kisah nabi Musa As, menyebutkan nama malaikat, kolase huruf hijaiyyah, Pada pembelajaran ini anak belajar tentang konsep perbuatan baik dan buruk, mengamati, mengumpulkan informasi, mengasosiasi dan mengkomunikasikan.

Kegiatan main pendekatan saintifik untuk anak usia 4-5 tahun disetiap sentra yakni pada sentra seni: membedakan rumah adat suku toraja dan bugis, mewarnai tulisan budaya dan kolase. Pada kegiatan diatas anak melakukan kegiatan mengamati benda yang diwarnai dan yang ditempel, menanya kegiatan yang dilaksanakan, mengasosiasi, mengumpulkan informasi dan mengkomunikasikan benda yang diwarnai dan ditempel. Menggambar rumah adat, menebalkan bilangan dan kata. Pada pembelajaran ini anak melakukan kegiatan mengamati penulisan huruf dan angka, menanya, mengasosiasi rumah adat, baju adat, tarian, mengumpulkan informasi, mengkomunikasikan terkait rumah adat Makassar dan Toraja, budaya nasional yakni tarian, rumah adat dan baju adat dibeberapa daerah. Anak membuat gelang suku mandar dari bahan pipet warna warni dan tali rapiah. Media disiapkan sesuai dengan tema yang sedang dipilih. Pada kegiatan ini anak melakukan kegiatan pengamatan tentang cara membuat gelang, menanya, mendapatkan informasi tentang gerakan mencangkul yang dilakukan petani di sawah, serta bagaimana bersikap pada saat mati lampu, mengasosiasi dan meng-komunikasikan hasil karya berupa gelang pada teman atau guru.

\section{Perkembangan Bahasa Anak Di TK Asoka Makassar}

Kemampuan bahasa memiliki empat keterampilan yaitu menyimak, berbicara, membaca dan menulis. Ada empat skala yang digunakan yaitu: BB,MB,BSH,BSB. BB artinya belum berkembang; Bila anak melakukan harus dengan bimbingan atau di contohkan oleh guru. MB artinya Mulai berkembang; Bila anak melakukan masih harus diingatkan atau dibantu oleh guru. BSH artinya Berkembang Sesuai Harapan; Bila anak sudah dapat melakukannya secara mandiri dan konsisten tanpa harus diingatkan atau di contohkan oleh guru. BSB artinya Berkembang Sangat Baik; Bila anak sudah dapat melakukannya secara mandiri dan sudah dapat membantu temannya yang belum mencapai kemampuan sesuai dengan indikator yang diharapkan. Pada umur 4-6 tahun sudah terbiasa dengan konsep perbincangan seperti yang nampak anatra bu Mariyani dan murid. Sekarang kita gantian berbicara, ibu guru dahulu yang berbicara selanjutnya anakanakku yang berbicara. Dan dapat melatih keterampilan bercakap-cakap sekaligus menumbuhkan percaya diri karena merasa pembicaraannya didengar. Bu guru saya ingin menempel hurufnya dengan serutan pensil yang paling besar. Selanjutnya menciptakan kesempatan bercerita bagi anak terkait pengalamannya sesuai pembelajaran sentra pada hari itu Sewaktu ditanya oleh ibu guru tentang makanan pavoritnya Raihan menjawab saya suka makan bakso di mall Ratu Indah bersama Ayah dan Ibu. dan sewaktu bu guru bertanya apa ciri budaya Toraja terkait tema budaya pada hari itu, Dinda kemudian menjawab saya orang Toraja kalau orang Toraja meninggal ada pesta bu guru. Kegiatan bermain merupakan salah satu cara bagi anak mengembangkan kemampuan berbahasanya. Ketika Aqilah berbincang dengan kolase huruf hijaiyyah pada gambarnya, pada saat kolase huruf hijaiyyah dengan mengatakan saya tempel gambarnya pakai serutan pensil yang seperti rok besar yang warnanya bagus dan cantik. Menyimak bagi anak umur 5-6 tahun dapat dilakukan dengan melaksanakan perintah yang lebih kompleks sesuai dengan aturan yang disampaikanbu guru pada saat anak bermain di sentra balok. Aturan mainnya adalah, gunakan balok secukupnya, ambil balok secukupnya, dan setelah bermain, mainan dibereskan dan dikembalikan ketempat semula. Bermain peran dapat mengajarkan anak berlatih untuk menggunakan bahasa yang baku dan percakapan praktis yang berlangsung sehari hari misalnya pada sentra bermain peran dengan tema jual beli/makan direstoran, anak yang berperan sebagai pencatat menu akan bertanya kepada pelanggan restoran menu apa yang akan dipesan pada saat itu. Bermain huruf dengan menyebutkan kata-kata yang memiliki huruf depan tertentu. Misalnya huruf 
dari kata rumah pada saat anak belajar tentang rumah adat yakni $\mathrm{R}$ untuk rusa, $\mathrm{U}$ untuk unta, $\mathrm{M}$ untuk manggis, A untuk apel, $\mathrm{H}$ untuk harimau. Bertanya memberikan kesempatan pada anak untuk keterampilan berbahasanya seperti pada saat anak umur 4-5 tahun belajar di sentra seni, Atifah bertanya pada bu guru apa boleh beda belajarnya, ketika bu guru Lia mengatakan kita belajar dua kegiatan yakni menempel dan mewarnai dengan tempat pelaksanaan yang berbeda sambil menunjuk tempatnya. dan pada saat anak umur 5-6 tahun bertanya kepada bu guru Min pada pelaksanaan pembelajaran saintifik di sentra bahan alam, ketika ujung bawah tissue yang dicelupkan ke dalam air berwarna tapi lama kelamaan seluruh tissue sampai ujung atas basah semua, yang selanjutnya dijawab oleh bu guru kalau itu namanya menyerap seperti halnya tanaman yang mengisap/menyerap makanan dari dalam tanah. Ini sejalan dengan wawancara dengan ibu Nurmala selaku kepala sekolah Taman Kanak kanak Asoka yang menyatakan bahwa; Pelaksanaan pendekatan saintifik sangat mendukung perkembangan bahasa anak dimana terjadi interaksi tanya jawab antar anak dan ibu guru, anak anak diberi kesempatan untuk mengamati suatu benda yang telah diperlihatkan oleh ibu guru sesuai tema dan anak-anak diminta menyampaikan apa yang dilihatnya. Membaca usia 5-6 tahun anak mulai belajar menggunakan buku, melihat dan membalik lembaran buku ataupun membawa buku kesukaannya sedangkan pada usia 4-5 tahun anak berpura-pura membaca buku/gambar dan memaknai gambar berdasarkan pengalaman yang diperoleh sebelumnya. Menulis usia 5-6 tahun dilakukan dengan menulis angka sesuai dengan jumlah murid laki-laki dan perempuan yang hadir pada hari itu, bu guru menugaskan sambil menjelaskan cara menulis angka. Usia 4-5 tahun dengan menebalkan tulisan pada gambar rumah adat, menebalkan bilangan dan kata dengan menggunakan pensil, dan menghubungkan kata dengan gambar. Pelaksanaan pendekatan saintifik dalam pengembangan bahasa anak terlaksana dalam kegiatan pembelajaran disetiap sentra meskipun belum maksimal karena pelaksanaannya adalah hal yang baru bagi pembelajaran di PAUD dan tenaga pendidik masih proses belajar dan menyesuaikan pembelajaran dengan pendekatan saintifik sebagai implementasi kurikulum 2013, tetapi peningkatan hasil belajar peserta didik sudah terlihat baik motivasi belajar maupun hasil pembelajaran. Dari hasil pengamatan untuk anak umur 5-6 tahun (kelas B), Pada aspek menyimak, dari 15 orang murid kelas B2 sebanyak 13 orang anak mengarah pada kemampuan Berkembang Sangat Baik, 1 orang mengarah pada kemampuan Berkembang Sesuai Harapan yaitu 1 orang mengarah pada kemampuan Mulai Berkembang, pada aspek berbicara 12 anak mengarah pada kemampuan Berkembang Sangat Baik, 2 orang mengarah pada kemampuan Berkembang Sesuai Harapan dan 1 orang mengarah pada kemampuan Mulai Berkembang, pada aspek membaca dan menulis 14 orang anak mengarah pada kemampuan Berkembang Sangat Baik dan 1 orang mengarah pada kemampuan Mulai Berkembang disebabkan adanya gangguan pada tahap perkembangannya. Sedangkan pada anak umur 4-5 tahun (kelas A) pada aspek menyimak kemampuan anak mengarah kepada Berkembang Sesuai Harapan, begitupula pada aspek berbicara mengarah kepada Berkembang Sesuai Harapan, dan untuk aspek membaca serta menulis kemampuan anak mengarah kepada Berkembang Sesuai Harapan. Pendekatan saintifik memunculkan motivasi anak belajar melalui bermain.

\section{Hubungan pelaksanaan pendekatan saintifik} dendan tingkat perkembangan bahasa anak

Melalui pendekatan saintifik perkembangan bahasa anak dapat berkembang dengan optimal, tentunya jika tahapan-tahapan saintifik itu sendiri mendapat dukungan yang baik dari ibu guru mulai dari tahapan mengamati, menanya anak diberi kesempatan untuk bertanya lalu mengumpulkan informasi kemudian menalar dan mengkomunikasikan.

\section{PEMBAHASAN}

Pembelajaran pendekatan saintifik dilakukan dengan proses mengamati, menanya, mengumpulkan informasi, mengasosiasi, dan mengkomunikasikan yang dilakukan oleh murid didampingi oleh guru dengan metode pembelajaran yang dilakukan oleh guru dengan bercerita, pemberian tugas/praktek langsung dan demonstrasi atau seni peran. Pada anak usia dini pengenalan proses saintifik dilakukan dengan cara melibatkan anak langsung dalam kegiatan; yakni melakukan, mengalami pencarian informasi dengan bertanya, mencari tahu jawaban. 
Dengan pendekatan saintifik secara langsung anak mengamati dan mengutak atik sendiri benda yang ada disekitarnya sehingga anak akan melihat langsung bagaimana keteratutan dan pola struktur yang terdapat dalam benda yang sedang diperhatikannya. Hasil pengamatan tersebut kemudian anak hubungkan dengan keterangan intuitif yang sudah melekat pada dirinya. Hal ini sejalan dengan Teori belajar yang dikemukakan oleh Bruner yang mengungkapkan bahwa dengan memanipulasi alat peraga anak dapat belajar melalui keaktifannya, proses ini memungkinkan anak menemukan hal hal baru diluar (melebihi) informasi yang sudah diberikan kepadanya. Jadi pada tahap ini anak belajar suatu pengetahuan dimana pengetahuan itu dipelajari secara aktif, dengan menggunakan benda benda kongkrit atau menggunakan situasi yang nyata. Pada penyajian ini anak menggunakan imajinasinya, ia akan memahami sesuatu dari berbuat atau melakukan sesuatu.

Dalam proses perumusan dan mengkonstruksi atau menyusun ide ide apabila disertai dengan bantuan benda benda kongkrit mereka lebih muda mengingat ide ide tersebut. Dengan demikian, anak lebih muda menerapkan ide dalam situasi nyata secara tepat. Seperti yang diuraikan pada penjelasan tentang strategi pembelajaran, akan lebih baik jika para peserta didik mula mula diperlihatkan benda dan kejadian yang kongkrit yang memungkinkan untuk aktif, tidak hanya aktif secara intelektual (mental) tetapi juga secara fisik dan kemampuan untuk berpikir secara bebas. Pengetahuan itu bertahan lama dan lebih muda di ingat jika dibandingkan dengan pengetahuan yang dipelajari dengan cara cara lain.

Bahasa menjadi lebih penting sebagai suatu media berpikir. Seseorang mencapai masa transisi yang didasarkan pada penginderaan ke penyajian yang didasarkan berpikir abstrak. Teori Stimulus Organism Respon berpandangan bahwa belajar merupakan suatu proses interaksi yang mencakup ingatan, retensi pengolahan informasi, emosi, dan aspek aspek kejiwaan yang lainnya. Belajar merupakan aktifitas yang melibatkan proses berpikir yang sangat kompleks. Proses belajar terjadi antara lain mencakup pengaturan stimulus yang diterima dan menyesuaikan dengan struktur kognitif yang sudah dimiliki dan terbentuk dalam pikiran seseorang berdasarkan pemahaman dan pengalaman sebelumnya.

Bahasa adalah pola dasar simbolik dimana peserta didik memanipulasi simbol simbol atau lambang dari benda ataupun kejadian tertentu. Ini sejalan dengan tahapan perkembangan mereka.

Dengan mengamati hasil selama pelaksanaan pendekatan saintifik maka ada beberapa hal yang dapat diamati yaitu walaupun metode pendekatan saintifik ini memberikan kesenangan bagi peserta didik, tetapi pembelajarannya tetap harus memperhatikan proses dari setiap tahapan peserta didik itu sendiri, Proses belajar akan berjalan dengan baik dan kreatif jika guru memberikan kesempatan kepada anak untuk menemukan suatu konsep, teori, aturan, dan pemahaman melalui contoh contoh yang dijumpai dalam kehidupannya sendiri.

Anak berusaha sendiri untuk mencari pemecahan masalah serta pengetahuan yang menyertainya menghasilkan pengetahuan yang benar benar bermakna (yaitu kegiatan belajar dengan pemahaman). Dengan kondisi peserta didik (subjek penelitian) yang berada pada level kognitif pra-operasional kongkrit yaitu tahap persiapan kearah cara berpikir sesuai yang ditangkap oleh indera dan konsep telah ada dalam pikiran mereka yang didasarkan pada pengertian dan pengalaman yang diperolehnya sendiri (persepsi sendiri), maka guru perlu tekun dan bersabar dalam mendampingi dan memahami kondisi yang beragam dari setiap peserta didiknya. Perkembangan anak merupakan proses pengukuran terhadap hasil dari kegiatan belajar anak. Penilaian kegiatan belajar di PAUD menggunakan penilaian autentik. Penilaian autentik merupakan penilaian proses dan hasil belajar untuk mengukur tingkat pencapaian kompetensi sikap (spiritual dan social), pengetahuan, dan keterampilan berdasarkan fakta yang sesungguhnya. Penilaian dilakukan secara sistematis, terukur, berkelanjutan dan menyeluruh yang mencakup pertumbuhan dan perkembangan yang telah dicapai oleh anak selama kurun waktu tertentu.

\section{KESIMPULAN DAN SARAN}

Pelaksanaan pendekatan saintifik dalam pengembangan bahasa anak terlaksana dalam kegiatan pembelajaran disetiap sentra meskipun belum maksimal karena pelaksanaannya adalah hal yang baru bagi 
pembelajaran di PAUD. Perkembangan bahasa anak mencakup aspek bahasa anak yaitu, menyimak, berbicara, membaca dan menulis untuk meningkatkan kemampuan berbahasa anak. Perkembangan bahasa anak usia 5-6 tahun mengarah kepada Berkembang Sangat Baik, dan untuk anak usia 4-5 tahun mengarah kepada Berkembang Sesuai Harapan. Terdapat hubungan pendekatan saintifik dengan perkembangan bahasa anak, dengan pendekatan saintifik memunculkan motivasi anak untuk belajar melalui bermain. Dengan pendekatan saintifik maka perkembangan bahasa anak di TK Asoka dapat ditingkatkan.

\section{DAFTAR PUSTAKA}

Cangara, 2012. Pengantar Ilmu Komunikasi. Ed. 2, Cet. 13, PT. Rajagrafindo Persada, Jakarta

Gunarti,Wida dkk 2008. Metode Pengembangan Prilaku dan kemampuan dasar Anak Usia Jakarta. Departemen Pendidikan Nasional.

Harapan Edi dan Ahmad Syarwani. 2014. Komunikasi Antarpribadi: Prilaku Insani Dalam Organisasi Pendidikan. PT. RajaGrafindo Persada, Jakarta

Harun Rasyid, Mansyur \& Suratno. (2009). Asesmen Perkembangan Anak Usia Dini. Yogyakarta: Multi Pressindo.

Munastiwi Erni (2015). Implementasi Pendekatan Saintifik pada Pembelajaran Anak Usia Dini (PAUD). Universitas Negeri Sunan Kalijaga Yogyakarta.

Wahyuningsih Sri (2015). Implementasi kurikulm 2013 paud di TKIT Bina Amal Kota Semarang Jurusan Pendidikan Anak Usia Dini, Fakultas Ilmu Pendidikan, Universitas Negeri Semarang 